\title{
In vivo phagocytosis and hematology in Astyanax altiparanae, a potential model for surrogate technology
}

\author{
N. Levy-Pereira ${ }^{a, b *}$ (D), G. S. Yasui ${ }^{b, c}$ (D), M. M. Evangelista ${ }^{a, b}$ (D), N. F. Nascimento ${ }^{a}$ \\ M. P. Santos ${ }^{a}$ (D), D. H. Siqueira-Silva ${ }^{d, e}$ (D), P. S. Monzani ${ }^{b, d}$ (D), \\ J. A. Senhorini ${ }^{b, c}$ (D) and F. Pilarski ${ }^{a}$ (D)
}

${ }^{\text {a}}$ Laboratório de Microbiologia e Parasitologia de Organismos Aquáticos - LAPOA, Centro de Aquicultura da UNESP CAUNESP, Universidade Estadual Paulista - UNESP, Via de Acesso Prof. Paulo Donato Castellane, s/n, CEP 14884-900, Jaboticabal, SP, Brasil

${ }^{\text {b} L a b o r a t o ́ r i o ~ d e ~ B i o t e c n o l o g i a ~ d e ~ P e i x e s, ~ I n s t i t u t o ~ C h i c o ~ M e n d e s ~ d e ~ C o n s e r v a c ̧ a ̃ o ~ d a ~ B i o d i v e r s i d a d e ~-~ I C M B i o, ~}$ Rodovia Pref. Euberto Nemésio Pereira de Godoy, CEP 13630-970, Pirassununga, SP, Brasil

'Instituto de Biociências - IBB, Universidade Estadual Paulista - UNESP, Rua Prof. Doutor Antonio Celso Wagner Zanin, s/n, CEP 18618-689, Botucatu, SP, Brasil

¿Departamento de Medicina Veterinária, Universidade de São Paulo - USP, Av. Duque de Caxias Norte, 225, Zona Rural, CEP 13635-900, Pirassununga, SP, Brasil

'Instituto de Saúde e Estudos Biológicos - IESB, Universidade Federal do Sul e Sudeste do Pará - UNIFESSPA, Folha 31, Quadra 7, Lote Especial, s/n, CEP 68507-590, Marabá, PA, Brasil

*e-mail: nycolas.pereira@zootecnista.com.br

Received: June 29, 2018 - Accepted: October 31, 2018 - Distributed: May 31, 2020

(With 3 figures)

\begin{abstract}
Although the potential of surrogate propagation technology for aquaculture and conservation of Neotropical fish, the poor understanding of the host immune system may results in rejection and destruction of the donor material. Thus, it is necessary to study and to develop methods to evaluate the effects of immunosuppressive drugs employment and to evaluate the immunocompatibility between donor and receptor. Thus, the present study aimed to optimize a methodology to assess in vivo phagocytosis in Astyanax altiparanae using Saccharomyces cerevisiae and to evaluate their hematological response resultant from the inflammatory induction. To this, $S$. cerevisiae were labeled with Congo

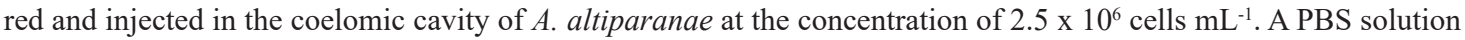
and a non-injected group were kept as control. Fish blood was sampled and the phagocytic capacity and index were determined at 1, 2, 3 and $6 \mathrm{~h}$ post-injection (hpi). The yeast injection successfully stimulated phagocytosis, with the best result for phagocytosis assessment after 2 hpi. Moreover, it was achieved a high traceability of phagocytized and non-phagocytized yeast under optic microscopy analysis due to the Congo red labeling. The hematological profile was similar to usually observed in early infections, indicating lymphocyte migration to inflammatory site and increase in number of circulating phagocytes due to natural response to inflammatory stimulus. In conclusion, our method was efficient to assess in vivo phagocytosis in A. altiparanae and will be an important tool to evaluate the efficacy of immunosuppressive drugs in this species. Additionally, these results may serve as support for further studies in fish immunocompetence, both in laboratory and in field conditions.
\end{abstract}

Keywords: surrogate technology host, hematology, innate immune response, Neotropical fish.

\section{Fagocitose in vivo e hematologia em Astyanax altiparanae, um potencial modelo para tecnologia de propagação mediada}

\section{Resumo}

Apesar do potencial apresentado pela tecnologia de propagação mediada para a aquicultura e conservação de peixes Neotropicais, o pobre entendimento do sistema imune do hospedeiro pode resultar na rejeição e destruição do material do doador. Com isso, se fazem necessários o estudo e o desenvolvimento de métodos para análise tanto dos efeitos de drogas imunossupressoras quanto para a avaliação da imunocompatibilidade entre doadores e receptores. Logo, o presente estudo teve como objetivo aperfeiçoar um método para analisar a fagocitose in vivo em Astyanax altiparanae usando Saccharomyces cerevisiae marcado e avaliar seu perfil hematológico resultante da indução inflamatória. Para isso, $S$. cerevisiae foram marcados com vermelho Congo e injetados na cavidade celomática dos A. altiparanae na concentração de $2,5 \times 10^{6}$ células. $\mathrm{mL}^{-1}$. Peixes injetados com PBS e peixes não injetados foram mantidos como controle. 
Sangue foi colhido e a capacidade fagocítica e o índice fagocítico foram determinados após 1, 2, 3 e 6 horas após à injeção (hpi). A injeção de levedura estimulou a fagocitose com sucesso, com o melhor resultado atingido após 2 hpi. Ainda, foi observada uma alta rastreabilidade das leveduras fagocitadas e não fagocitadas sob microscopia óptica devido à marcação com vermelho Congo. O perfil hematológico foi similar ao observado usualmente em infecções recém-induzidas, indicando migração de linfócitos ao sítio inflamatório e aumento no número de fagócitos circulantes devido à resposta natural ao estímulo inflamatório. Como conclusão, nosso método foi eficiente para analisar a fagocitose in vivo em A. altiparanae e será uma ferramenta importante para a avaliação de eficácia de drogas imunossopressoras para esta espécie. Em adição, estes resultados podem contribuir para futuros estudos em imunocompetência em peixes, tanto em âmbito laboratorial quanto a campo.

Palavras-chave: receptor para propagação mediada, hematologia, resposta imune inata, peixes neotropicais.

\section{Introduction}

The surrogate technology is suitable not only to attend the increasing demand for fish as food but also to assist conservation efforts to minimize the impact on natural fish stock (Yamaha et al., 2007). Despite its potential, the current efficacy regarding the surrogate propagation is still low (Lin et al., 1992; Takeuchi et al., 2003, 2004; Yoshikawa et al., 2017), especially within inter-specific transplantation (Saito et al., 2008; Higuchi et al., 2011; Yasui et al., 2011; Morita et al., 2015). The most probable explanation is the activation of the host immune system by the transplanted cells, triggering both innate and adaptive responses and culminating in the destruction of the donor material, as observed in mammals (Abbas et al., 2014). Because of this, the interest to use immunosuppressant drugs such as cyclosporine (Xing et al., 2017), cyclophosphamide (Kumari and Sahoo, 2005) and some steroids (Walsh et al., 2002) in order to avoid such effects in fish is increasing, as well as the necessity for a better understanding of the immunity of the species chosen as host. Therefore, these factors give rise to the necessity of development and optimization of techniques to evaluate the efficacy of such substances and to assess how they modulate the immune parameters of the host, such as the phagocytosis.

The phagocytosis is considered the first cellular innate immune response against pathogens and is the end point of several humoral responses such as complement activity and antibody opsonization (Secombes and Fletcher, 1992; Tizard, 2014). In fish, as in other vertebrates, the phagocytosis is a complex processes in which the phagocytes, usually granulocytes, monocytes and macrophages, recognize and engulf microorganisms or foreign particles, destroying them with endogenously produced antimicrobial substances (Neumann et al., 2001; Marques et al., 2003; Rossi et al., 2009). Phagocytosis is also important in rejection processes, participating in the destruction of the exert, in the antigen presentation and in the production of interleukins (Abbas et al., 2014; Tizard, 2014). On the other hand, in contrast to mammals, thrombocytes (Tavares-Dias et al., 2007; Nagasawa et al., 2015) and B lymphocytes (Li et al., 2006) of fish were described as having phagocytic potential as well.

Several factors such as stress (Law et al., 2001), xenobiotics (Girón-Pérez et al., 2006; Paul et al., 2014) and immunostimulants (Zhu et al., 2012; Biller-Takahashi et al.,
2014; Dotta et al., 2014, 2015; Farias et al., 2016) can affect the innate immune response of fish, what makes phagocytic assays an important tool for the evaluation of fish immunocompetence. However, few are the information regarding phagocytosis in Neotropical species (Jensch-Junior et al., 2006; Dias et al., 2011; Nunes et al., 2014; Farias et al., 2016).

The yellow tail tetra Astyanax altiparanae (Garutti and Britski, 2000) is a small fish (8-14 cm), easy to handle and to reproduce, with a great capacity of adaptation to a wide range of environmental conditions, easy for blood collection without the necessity for euthanasia, as well as to perform in vitro fertilization, with high fertility, with each female producing an average of 8000 eggs (Agostinho and Gomes, 1997; Lobón-Cerviá and Bennemann, 2000; Andrian et al., 2008). Additionally, the genus Astianax encloses more than 300 species, which are widely distributed in the Neotropical region (GBIF, 2016).

Recently, our research group developed studies concerning A altiparanae basic reproduction (Yasui et al., 2015), early development (Santos et al., 2016) and triploidy induction (Adamov et al., 2016), with confirmed sterility to female and impaired gonadal development in males (Nascimento et al., 2017a, b), showing that the species have a great potential as experimental model for studies in surrogate propagation technology.

Thus, the present study aimed to optimize an in vivo phagocytosis protocol for A. altiparanae using labeled Saccharomyces cerevisiae and to observe the hematological profile resultant from the induced inflammation.

\section{Material and Methods}

\subsection{Ethics}

All the experimental procedures were performed in accordance to the National Council of Animal Experimentation Control (CEBEA) and Commission for Animal Use Ethics (CEUA) (protocol \#02031.000040/201512).

\subsection{Fish and experimental conditions}

For the experiment, 122 specimens of $A$. altiparanae (18 months old, $8.66 \pm 2.35 \mathrm{~g}, 66.41 \pm 7.02 \mathrm{~mm}$ ) obtained from the ponds of Centro Nacional de Pesquisa e Conservação da Biodiversidade "Chico Mendes" (CEPTA/ICMBio, Pirassununga, Brazil) were randomly distributed in six $100 \mathrm{~L}$-aquaria. The fish were maintained with continuous 
aeration and constant temperature $\left(28 \pm 0.5^{\circ} \mathrm{C}\right.$ maintained with temperature controller) during 30 days for acclimation. Each aquarium had $20 \%$ of the water changed daily and the water quality parameters during this period were temperature of $27.8 \pm 0.6^{\circ} \mathrm{C}$, dissolved oxygen of $5.6 \pm 0.9$ g.dL $\mathrm{dL}^{-1}$ and $\mathrm{pH}$ of $5.9 \pm 0.4$.

\subsection{Yeast preparation}

Saccharomyces cerevisiae (Fleishman, Brazil) were prepared by adaptation of method described by Kaminski et al. (1985). Briefly, $1.5 \mathrm{~g}$ of the yeast was added to $5 \mathrm{~mL}$ of PBS ( $\mathrm{NaCl} 0.137 \mathrm{M}, \mathrm{KCl} 2.7 \mathrm{mM}, \mathrm{KH}_{2} \mathrm{PO}_{4} 1.5 \mathrm{mM}, \mathrm{Na}_{2} \mathrm{HPO}_{4}$ $8.1 \mathrm{mM}, \mathrm{CaCl}_{2} 0.9 \mathrm{mM}, \mathrm{MgCl}_{2} 0.49 \mathrm{mM}$ in Milli-Q water, $\mathrm{pH} 7.4$ ) containing $0.83 \%$ of Congo red in a $15 \mathrm{~mL}$ plastic tube (Falcon) and left to stain during $15 \mathrm{~min}$. Then, $7 \mathrm{~mL}$ of Mili-Q water was added to the solution and autoclaved for $15 \mathrm{~min}$. After this, the yeast was washed centrifuging the tubes at $250 \mathrm{G}$ by $5 \mathrm{~min}$ and completing the volume until $10 \mathrm{~mL}$ with autoclaved PBS. This procedure was repeated until the removal of the dye excess. Then, the yeasts were suspended one last time in autoclaved PBS and stored at $4{ }^{\circ} \mathrm{C}$ until the use. Before the injection, the solution was corrected to $2.5 \times 10^{6}$ cell $\mu \mathrm{L}^{-1}$.

\subsection{Experimental design and sampling}

The experiment was conducted in six days. In each day, fish from one aquarium were caught and anesthetized in eugenol solution $\left(0.1 \mathrm{~mL} \mathrm{~L}^{-1}\right.$ of water $)$ and divided in three groups. A group of fish had $0.1 \mathrm{~mL}$ of the yeast solution were injected (Yeast group) in the coelomic cavity under the left pectoral fin using $1 \mathrm{~mL}$ syringes attached to insulin needles (29 Gauge) and placed in a separated aquarium. Other group was injected with the same volume with PBS solution (PBS group) according to the same procedure and placed in the other aquarium. A third group of each aquarium was kept separately and treated as non-injected group (NI).

After the anesthesia, the NI fish had $100 \mu \mathrm{L}$ of blood collected by puncture of the caudal vein using $3 \mathrm{~mL}$ syringe coated with heparin solution (sodium heparin $100 \mathrm{IU}, 0.95 \%$ of $\mathrm{NaCl}$ ) attached to a 25 -gauge needle. The blood was stored in $1.5 \mathrm{~V}$-bottomed plastic tubes (Eppendorf, Germany). After 1, 2, 3 and 6 hours post injection (hpi), the fish from each group (PBS and Yeast) were anesthetized and had the blood collected according to the same procedure. After this, the fish of Yeast group were killed in concentrated eugenol solution $\left(1 \mathrm{~mL} \mathrm{~L}^{-1}\right.$ of water) and had the in vivo phagocytosis assessed.

After the sixth day of experiment, 10 fish were sampled from the NI group, 72 fish were sampled from Yeast group ( $n=18$ for each period of observation for phagocytosis and hematology) and 40 fish were sampled for PBS group ( $\mathrm{n}=10$ for each period of observation).

\subsection{Hematology}

The collected blood was used to the determination of hematology according to Ranzani-Paiva et al. (2013). For red blood cell (RBC) determination, $10 \mu \mathrm{L}$ of blood was diluted in $2 \mathrm{~mL}$ of formaldehyde-citrate solution and, after gently homogenization, the cells (RBC) were counted in Neubauer chamber. The hemoglobin was determined by kit (Labtest Diagnóstica S.A., Lagoa Santa, Brazil) where $10 \mu \mathrm{L}$ of blood was diluted in $2.5 \mathrm{~mL}$ of Drabkin's solution and the absorbance of the solution was determined in spectrophotometer $(540 \mathrm{~nm})$. To determination of the hematocrit, a glass microcapillary was filled with $50 \mu \mathrm{L}$ of blood, centrifuged for $5 \mathrm{~min}$ at $10,000 \mathrm{G}$, and the percentage of cells with a hematocrit reader plate. Hematimetric equations were used to determine Mean Corpuscular Volume $(\mathrm{MCV}=\mathrm{Ht} * 10 / \mathrm{RBC})$, mean corpuscular hemoglobin $(\mathrm{MCH}=\mathrm{Hb} * 10 / \mathrm{RBC})$ and Mean Corpuscular Hemoglobin Concentration $(\mathrm{CHCM}=\mathrm{Hb} * 100 / \mathrm{Ht})$. To the confection of the blood smears, $4.5 \mu \mathrm{L}$ of the heparinized blood were spread in glass slides, air-dried, and stained with May Grünwald-Gyemsa-Writh. After this, the total counting of thrombocytes and leukocytes was performed by counting 2,000 erythrocytes in several fields of the blood smear, and the differential count of leukocytes by counting 200 leukocytes.

\section{6. "in vivo" phagocytosis assay}

The phagocytosis assay was performed with a modification of the method described by Farias et al. (2016). Immediately after the blood sampling of fish from Yeast group (1, 2, 3 and 6 hpi), each fish was euthanized in concentrated eugenol solution and a ventral incision was carefully made using a bistoury. With a $200 \mu \mathrm{L}$-micropipette (Eppendorf, Germany), fish coelomic cavity was washed with $600 \mu \mathrm{L}$ of HBSS $(137 \mathrm{mM} \mathrm{NaCl}, 5.4 \mathrm{mM} \mathrm{KCl}$, $0.25 \mathrm{mM} \mathrm{Na}_{2} \mathrm{HPO}_{4}, 0.44 \mathrm{mM} \mathrm{KH} \mathrm{PO}_{4}, 1.3 \mathrm{mM} \mathrm{CaCl}{ }_{2}$, $1 \mathrm{mM} \mathrm{MgSO}_{4}, 4.2 \mathrm{mM} \mathrm{NaHCO}_{3}$ ) enriched with heparin $100 \mathrm{IU}$ and the cell suspension was placed in a $1.5 \mathrm{~mL}$ V-bottomed plastic tube (Eppendorf, Germany) and centrifuged at $250 \mathrm{G}$ during $5 \mathrm{~min}$. The tube containing the cells was stored in ice until the observation in microscopy. Then, the supernatant was discarded and the remaining cells were placed between glass slide and coverslip and observed under a magnitude of $400 \mathrm{X}$ using an optical microscope (Eclipse, Ci, Nikon NI, Tokyo, Japan) coupled to a CCD camera (DS Fil, Nikon NI, Tokyo, Japan) to the determination of the Phagocytic Capacity $(\mathrm{CP}=$ number of phagocytizing leukocytes / number of leukocytes * 100) and the Phagocytic Index (PI = number of yeast / number of phagocytizing leukocytes). Microphotographs of the coelomic wash were also taken using a magnitude of 1000x.

\subsection{Statistics}

Results are expressed as mean \pm standard error. The statistical analyses were performed with the software R V3.4.0. Data were checked for homoscedasticity and normality with Levene's test and Cramer-Von Mises' test, respectively. The hematological parameters were submitted to a Kruskal-Wallis test and to a non-parametric Tukey and Kramer test. The phagocytic parameters were submitted to ANOVA and the means were compared using Tukey's multiple range test. 


\section{Results}

The erythrocyte parameters can be observed in Figure 1. No differences were observed in $\mathrm{RBC}$ of fish due to yeast or PBS injection $(P=0.1395)$. The yeast injection resulted in a decrease in the Ht of fish when compared to NI and PBS groups $(P<0.0001)$, although no statistical differences were observed between Yeast and PBS in 2 and 3 hpi. Although the $\mathrm{Hb}$ of Yeast group increased when compared to NI fish at 2 and 3 hpi $(P=0.0049)$, no differences were observed between Yeast and PBS groups. The Yeast group presented lower MCV then NI fish in all periods of observation $(P<0.0001)$, but no differences were observed in relation to PBS. The $\mathrm{MCH}$ of the Yeast group was higher in all experiment, but the only statistical difference occurred between Yeast and PBS at $1 \mathrm{hpi}(P=0.0142)$. The yeast injected fish presented a higher MCHC then NI fish at 2 and 3 hpi, but not at 1 and $6 \mathrm{hpi}$, and only at $3 \mathrm{hpi}$ the MCHC of yeast group was statistically higher than the PBS group $(P=0.0008)$.

The leukocyte parameters are expressed in Figure 2. No significant differences were observed on thrombocytes numbers $(P=0.2259)$. No differences were observed in total leukocytes with exception in $3 \mathrm{hpi}$, when Yeast injected fish showed higher leukocytes then PBS group $(P=0.0367)$, but both similar to NI fish. Although statistically similar to PBS group, the Yeast group showed more than twice the number of monocytes in 2, 3 and 6 hpi, but only in this last period it presented a significant difference when compared to NI fish $(P<0.0001)$. A similar but stronger response was observed in Yeast group neutrophils, which were different from NI fish since 2 hpi and presented counts from twice to five times higher than PBS group, with
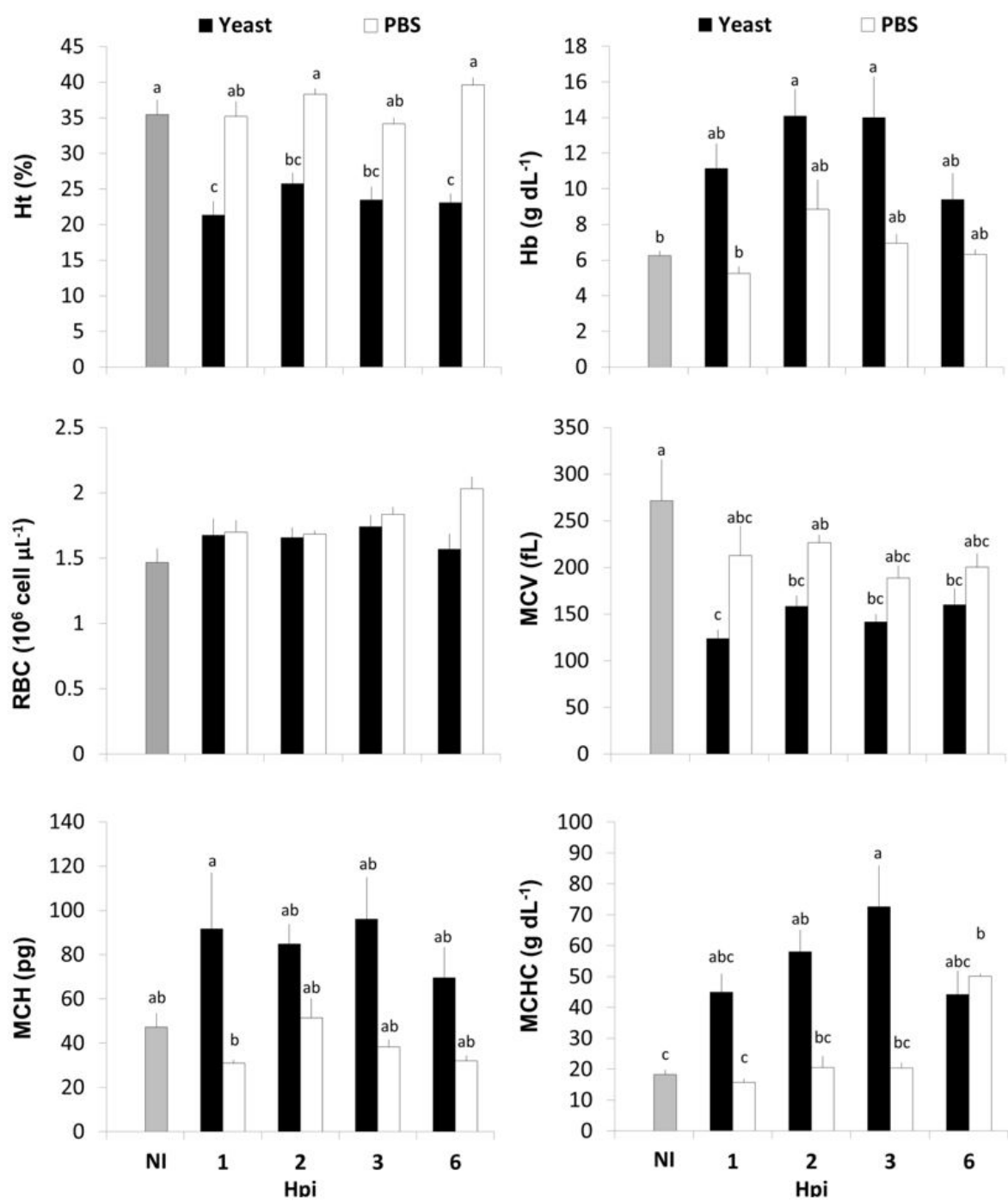

Figure 1. Erythrocyte parameters of A. altiparanae. $\mathrm{Ht}=$ hematocrit; $\mathrm{Hb}=$ hemoglobin; $\mathrm{RBC}=$ red blood cell; $\mathrm{MCV}=$ mean corpuscular volume; $\mathrm{MCH}=$ mean corpuscular hemoglobin; $\mathrm{MCHC}=$ mean corpuscular hemoglobin concentration; $\mathrm{NI}=$ non-injected; and Hpi $=$ hours post-injection. Different letters indicate different means $(P<0.05)$. 

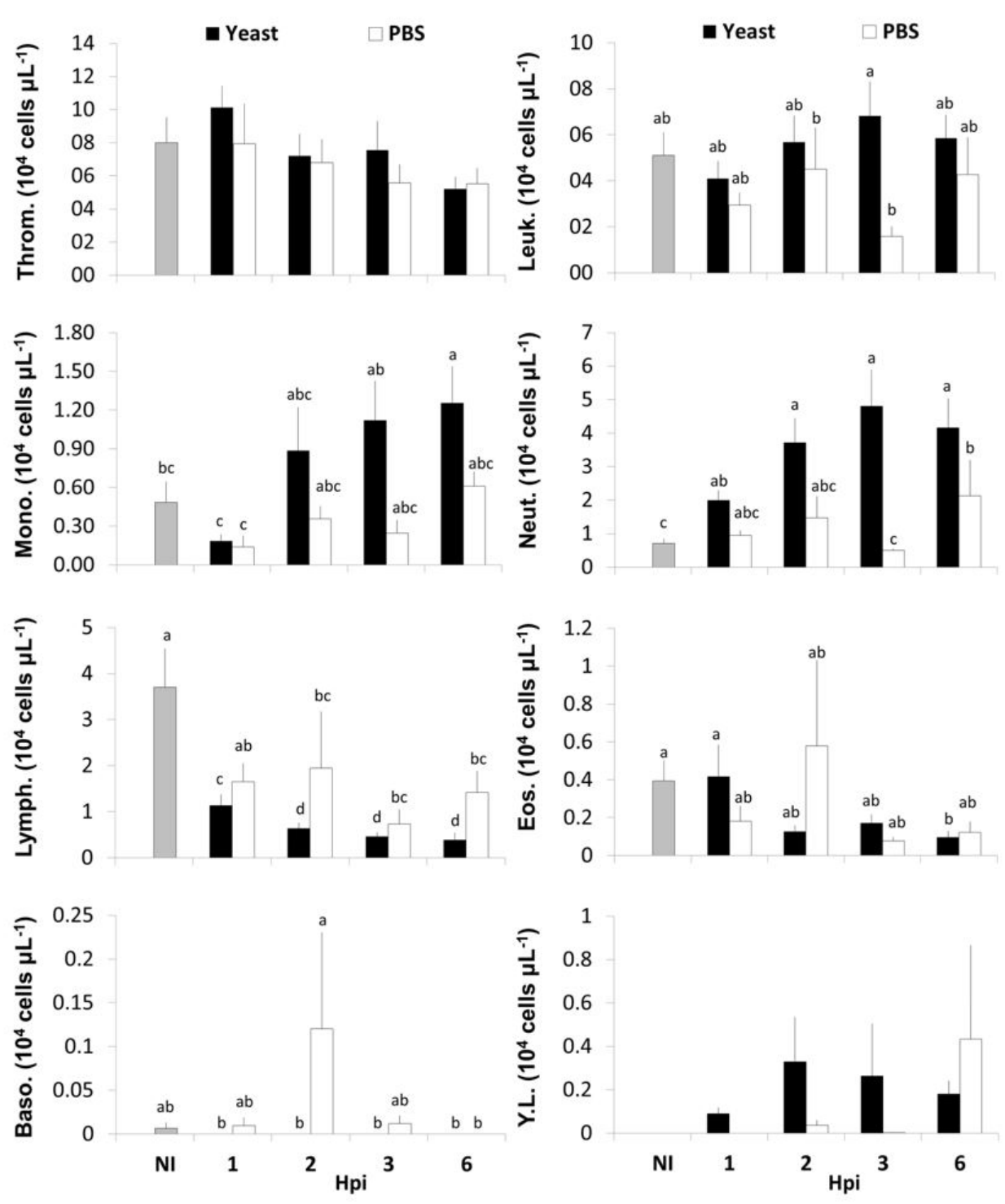

Figure 2. Leukocyte parameters of A. altiparanae. Throm. = Thrombocytes; Leuk. = Leukocytes; Mono. = Monocytes; Neut. $=$ Neutrophils; Lymph. $=$ Lymphocytes; Eos. = Eosinophils; Baso. = Basophils; Y.L. = Young Leukpcytes; $\mathrm{NI}=$ non-injected; and $\mathrm{Hpi}=$ hours post-injection. Different letters indicate different means $(P<0.05)$.

significant differences between those groups in 3 and 6 hpi $(P<0.0001)$. The lymphocytes of all injected fish were lower than NI fish, and the Yeast group presented the lesser numbers of lymphocytes in all periods of observation, with a significant decrease after 2 hpi $(P<0.0001)$. The yeast injection induced mild changes in eosinophils, presenting a statistical difference from NI only after 6 hpi and no differences with PBS fish in any of the periods of observation $(P=0.0032)$. Although statistically similar to in NI group, the fish from yeast group presented no basophils in any of the periods $(P=0.0135)$, with a significant presence of those cells only on fish from PBS group at $2 \mathrm{hpi}$. The Yeast injection increased the number of young leukocytes in comparison of NI fish $(P=0.0093)$, and PBS group with exception with $6 \mathrm{hpi}$, although the post hoc analyses showed no difference among the means due the high presence of null observations.

In the phagocytic assay, PC (Figure 3A) was $13.22 \pm 4.18 \%$ at $1 \mathrm{hpi}$, increasing to $30.01 \pm 6.31 \%$ at $2 \mathrm{hpi}$ and then declining to $20.65 \pm 4.07 \%$ and $21.60 \pm 5.07 \%$ at 3 and 6 hpi $(P=0.0300)$, respectively, but no differences were observed in PI (Figure 3B) at any of the periods of observation $(P=0.0749)$. Several types of leukocytes were found on the coelomic cavity of $A$. altiparanae, and the two most common types are shown on Figures $3 \mathrm{C}$ and $3 \mathrm{D}$, of which the first represent, by far, the most abundant type. Figure 3C shows a moving neutrophil of which several structures were observed: a frontal membrane projection 

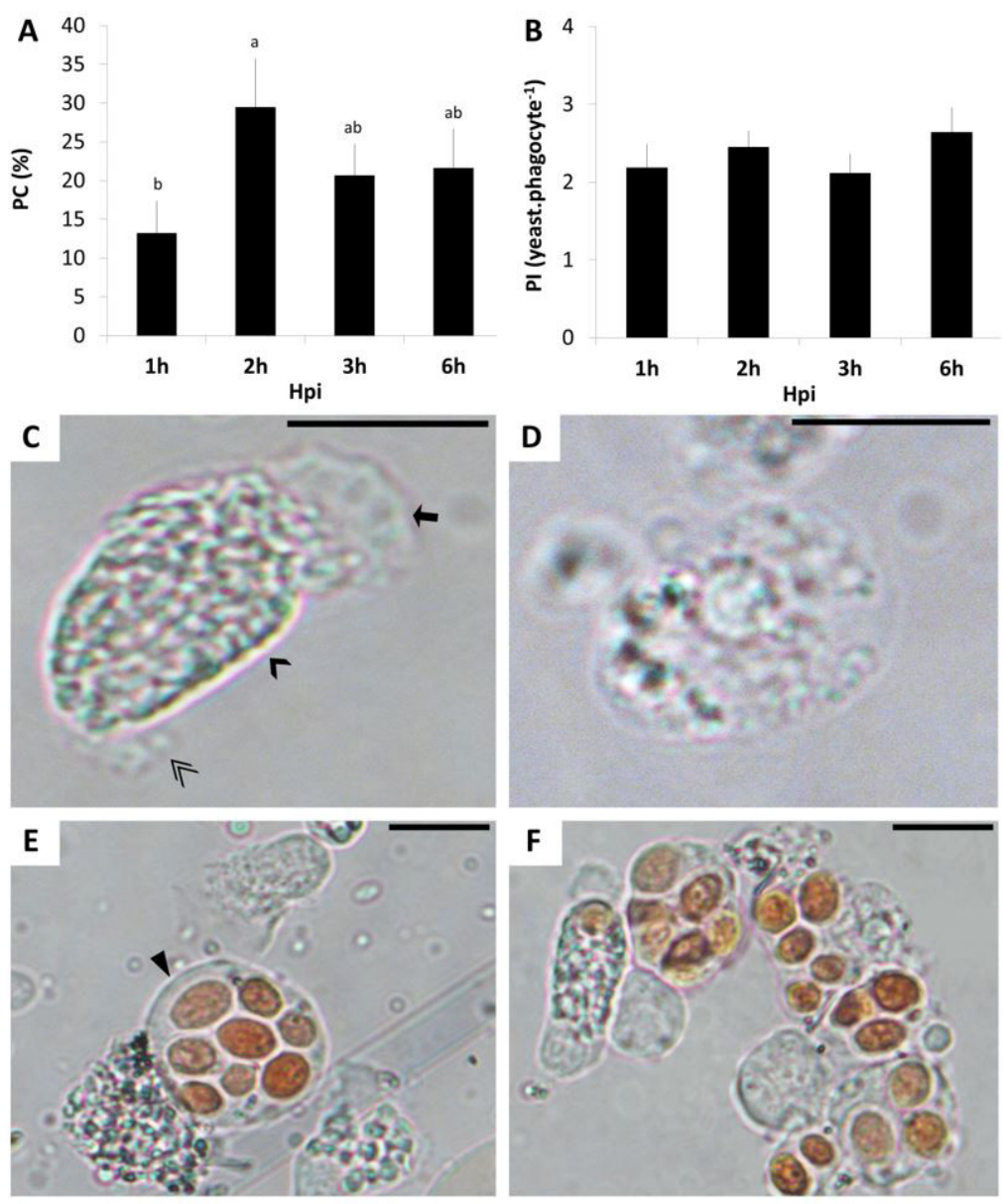

Figure 3. In vivo Phagocytic Capacity (A) and Phagocytic Index (B) of A. altiparanae after 1, 2, 3 and 6 hpi. Microphotographs of $A$. altiparanae phagocytes (C, D, E and F, fresh mount on glass slide, 1000x). Bar $=20 \mu \mathrm{m}$.

(arrow); the body rich of granules which is dragged forward by the frontal membrane projection (arrowhead); a tail-like membranous structure attached to the phagocytes rear (double arrowhead). Figure 3D shows a commonly found leukocyte with few granules, possible a degranulated neutrophil. In Figure 3E it is possible to observe the yeast cells already phagocytized, with emphasis (arrowhead) on the cytoplasmic membrane enclosing the yeasts. The Figure 3F shows a group of phagocytes, which was commonly observed, showing different kinds and sizes cells, some presenting engulfed yeasts.

\section{Discussion}

In the present study, S. cerevisiae inoculum was able to stimulate the phagocytic response in A. altiparanae. As in other species, possibly the presence of molecules on the yeast cell wall could be recognized as PAMPs (pathogen associated molecular patterns) by the PRRs (pathogen recognition receptors) expressed by leukocytes surfaces (Engstad and Robertsen, 1994; Kudrenko et al., 2009; Falco et al., 2014).
Previous researches assessing in vivo phagocytosis in fish described methods using phase contrast microscope (Silva et al., 2002, 2005; Dias et al., 2011; Nunes et al., 2014; Farias et al., 2016) in order to facilitate the observation of the phagocytized yeasts inside of coelomic phagocyte. In the present study, the $S$. cerevisiae labeling enhanced the traceability of phagocytosis by making the phagocytized yeasts possible to be observed and counted under conventional light microscopy. This can be considered an advantage since conventional microscopes are considerable less expensive than phase contrast microscopes and can be easily transported to field conditions.

In the present study, it was possible to observe that the best period to assess the phagocytosis in A. atiparnae was after 2 hpi. Similar results were described in Prochilodus linenatus (Jensch-Junior et al., 2006) and Pseudoplatystoma spp. (Nunes et al., 2014). According to Jensch-Junior et al. (2006) and Dias et al. (2011), this raise occurs due to the migration of phagocytes from blood and neighbor regions to the inflammatory site, although those authors did not describe such effect. Although phagocytes presenting 
8 or 9 yeasts were observed, the average PI stayed between 2 and 3 yeasts.phagocyte ${ }^{-1}$ during all the experiment, with no statistical significance overtime. This could be explained by the massive participation of neutrophils in the initial phagocytosis, which are leukocytes known to rapidly respond to a damage or invasion in the first hours of inflammation and to phagocytize a smaller number of particles than larger phagocytes such as monocytes/macrophages (Roberts, 2012).

Hematological parameters are widely used as a complementary method for evaluation of fish health. In the present study, the yeast injection was able to successfully change the hematological profile of fish, simulating an infection. The yeast injection resulted in a lower size of erythrocytes with higher hemoglobin content in contrast with the usual cell swelling due to stressful situations described by Railo et al. (1985) and Pitcher et al. (1992). In this study, the yeast injection resulted in a lower lymphocytes numbers in fish blood when compared to NI and PBS. The lymphocytes are immune mediators and antibody producer cells (Miller et al., 1998) and this reduction is explained by the fact that these cells are known to migrate to the inflammatory site in early inflammation (Martins et al., 2009). Neutrophils and monocytes numbers rose significantly in yeast group due to the immunostimulant effect caused by yeast wall components such as beta-glucan and mannan oligosaccharide, as discussed above. Both neutrophilia and monocytosis in the teleost blood are considered natural responses to the acute inflammatory phase caused by infection or injury (Suzuki and Iida, 1992; Roberts, 2012). Despite the hematological data presented, similar experiments showed few (Nunes et al., 2014) or no changes (Dias et al., 2011) in the leukocytes profile after yeast injection.

In conclusion, in this study, a high traceability of labeled yeast under conventional optical microscope was achieved, with the best time to assess in vivo phagocytosis in A. altiparanae after $2 \mathrm{hpi}$ and with the potential to simulate a hematological profile typical from an infection. This method will be an important tool to assess the use of immunosuppressant drugs in A. altiparanae in order to evaluate their applicability for surrogate technology. Also, this study could serve as support for further researches in immunology, immunotoxicology and immunomodulation for other aquaculture and wild species, as well as in studies performed in field condition due to its inexpensive methods and short period of execution. Further studies can be conducted in order to determine the profile of the migratory cell as well as of the resident coelomic population and their interaction.

\section{Acknowledgements}

We would like to thanks to Michael Stablein for the language review, to CAPES (scholarship \# 1.186.792), to Centro Nacional de Pesquisa e Conservação da Biodiversidade Aquática Continental (CEPTA/ICMBio) for the infrastructure and to AES Tietê for the financial support (project \# 4690000174).

\section{References}

ABBAS, A.K., LICHTMAN, A.H. and PILLAI, S., 2014 [viewed 20 May 2018]. Cellular and molecular immunology [online]. 8th ed. Philadelphia: Elsevier Health Sciences, 544 p. E-book. Available from: https://books.google.com.br/books?hl=pt-BR $\& 1 \mathrm{r}=\& \mathrm{id}=\mathrm{RWYWBAAAQBAJ} \& \mathrm{oi}=\mathrm{fnd} \& \mathrm{pg}=\mathrm{PP} 1 \& \mathrm{dq}=\mathrm{abb}$ as + immunology+2014\&ots=fuZ6e-txN_\&sig=Dp43PI2B$10 \mathrm{mvlS} 9 \mathrm{xPnRDvQxFzo} \# \mathrm{v}=$ onepage $\& \mathrm{q}=$ abbas $\% 20 \mathrm{immunology} \% 20$ $2014 \& \mathrm{f}=$ false

ADAMOV, N.S.D.M., NASCIMENTO, N.F.D., MACIEL, E.C.S., PEREIRA-SANTOS, M., SENHORINI, J.A., CALADO, L.L., EVANGELISTA, M.M., NAKAGHI, L.S.O., GUERRERO, A.H.M., FUJIMOTO, T. and YASUI, G.S., 2016. Triploid induction in the yellowtail tetra, Astyanax altiparanae, using temperature shock: tools for conservation and aquaculture. Journal of the World Aquaculture Society, vol. 48, no. 5, pp. 741-750. http://dx.doi.org/10.1111/jwas.12390.

AGOSTINHO, A.A. and GOMES, L.C., 1997. Reservatório de Segredo: bases ecológicas para o manejo. Maringá: EDUEM. Reservatório de Segredo: bases ecológicas para o manejo, pp. 97-111.

ANDRIAN, I.D.F., SILVA, H.B.R. and PERETTI, D., 2008. Dieta de Astyanax bimaculatus (Linnaeus, 1758) (Characiformes, Characidae), da área de influência do reservatório de Corumbá, Estado de Goiás, Brasil. Acta Scientiarum. Biological Sciences, vol. 23, pp. 435-440.

BILLER-TAKAHASHI, J.D., TAKAHASHI, L.S., MARZOCCHIMACHADO, C.M., ZANUZZO, F.S. and URBINATI, E.C., 2014. Disease resistance of pacu Piaractus mesopotamicus (Holmberg, 1887) fed with $\beta$-glucan. Brazilian Journal of Biology $=$ Revista Brasileira de Biologia, vol. 74, no. 3, pp. 698-703. http://dx.doi. org/10.1590/bjb.2014.0083. PMid:25296221.

DIAS, D.D.C., TACHIBANA, L., SERIANI, R., SANTOS, A.A., RANZANI-PAIVA, M.J.T. and ROMAGOSA, E., 2011. Tempo de migração dos macrófagos em matrinxãs, Brycon amazonicus por meio da técnica de inoculação de leveduras Saccharomyces cerevisiae. Acta Amazonica, vol. 41, no. 3, pp. 421-424. http:// dx.doi.org/10.1590/S0044-59672011000300013.

DOTTA, G., ANDRADE, J.I.A., TAVARES GONÇALVES, E.L., BRUM, A., MATTOS, J.J., MARASCHIN, M. and MARTINS, M.L., 2014. Leukocyte phagocytosis and lysozyme activity in Nile tilapia fed supplemented diet with natural extracts of propolis and Aloe barbadensis. Fish \& Shellfish Immunology, vol. 39, no. 2, pp. 280-284. http://dx.doi.org/10.1016/j.fsi.2014.05.020. PMid:24857767.

DOTTA, G., LEDIC-NETO, J., GONÇALVES, E., BRUM, A., MARASCHIN, M. and MARTINS, M., 2015. Acute inflammation and hematological response in Nile tilapia fed supplemented diet with natural extracts of propolis and Aloe barbadensis. Brazilian Journal of Biology $=$ Revista Brasileira de Biologia, vol. 75, no. 2, pp. 491-496. http://dx.doi.org/10.1590/1519-6984.02413. PMid:26132037.

ENGSTAD, R.E. and ROBERTSEN, B., 1994. Specificity of a $\beta$-glucan receptor on macrophages from Atlantic salmon (Salmo salar L.). Developmental and Comparative Immunology, vol. 18, no. 5, pp. 397-408. http://dx.doi.org/10.1016/0145-305X(94)90005-1. PMid:7698364.

FALCO, A., MIEST, J.J., PIONNIER, N., PIETRETTI, D., FORLENZA, M., WIEGERTJES, G.F. and HOOLE, D., 2014. $\beta$-Glucan-supplemented diets increase poly(I:C)-induced gene expression of Mx, possibly via Tlr3-mediated recognition 
mechanism in common carp (Cyprinus carpio). Fish \& Shellfish Immunology, vol. 36, no. 2, pp. 494-502. http://dx.doi.org/10.1016/j. fsi.2013.12.005. PMid:24370748.

FARIAS, T.H.V., LEVY-PEREIRA, N., ALVES, L.O., DIAS, D.C., TACHIBANA, L., PILARSKI, F., BELO, M.A.A. and RANZANI-PAIVA, M.J.T., 2016. Probiotic feeding improves the immunity of pacus, Piaractus mesopotamicus, during Aeromonas hydrophila infection. Animal Feed Science and Technology, vol. 211,pp. 137-144. http://dx.doi.org/10.1016/j.anifeedsci.2015.11.004.

GIRÓN-PÉREZ, M.I., BARCELÓS-GARCÍA, R., VIDALCHAVEZ, Z., ROMERO-BAÑUELOS, C. and ROBLEDOMARENCO, M., 2006. Effect of chlorpyrifos on the hematology and phagocytic activity of Nile tilapia cells (Oreochromis niloticus). Toxicology Mechanisms and Methods, vol. 16, no. 9, pp. 495-499. http://dx.doi.org/10.1080/15376510600751988. PMid:20020991.

GLOBAL BIODIVERSITY INFORMATION FACILITY - GBIF. “Astyanax" genus [online]. 2016. [viewed 20 May 2018]. Available from: https://demo.gbif.org/occurrence/map?q=astyanax

HIGUCHI, K., TAKEUCHI, Y., MIWA, M., YAMAMOTO, Y., TSUNEMOTO, K. and YOSHIZAKI, G., 2011. Colonization, proliferation, and survival of intraperitoneally transplanted yellowtail Seriola quinqueradiata spermatogonia in nibe croaker Nibea mitsukurii recipient. Fisheries Science, vol. 77, no. 1, pp. 69-77. http://dx.doi.org/10.1007/s12562-010-0314-7.

JENSCH-JUNIOR, B.E., PRESSINOTTI, L.N., BORGES, J.C.S. and SILVA, J.R.M.C., 2006. Characterization of macrophage phagocytosis of the tropical fish Prochilodus scrofa (Steindachner, 1881). Aquaculture, vol. 251, no. 2, pp. 509-515. http://dx.doi. org/10.1016/j.aquaculture.2005.05.042.

KAMINSKI, N.E., ROBERTS, J. and GUTHRIE, F., 1985. A rapid spectrophotometric method for assessing macrophage phagocytic activity. Immunology Letters, vol. 10, no. 6, pp. 329-331. http://dx.doi.org/10.1016/0165-2478(85)90127-0. PMid:3899925.

KUDRENKO, B., SNAPE, N. and BARNES, A.C., 2009. Linear and branched $B(1-3)$ d-glucans activate but do not prime teleost macrophages in vitro and are inactivated by dilute acid: Implications for dietary immunostimulation. Fish \& Shellfish Immunology, vol. 26, no. 3, pp. 443-450. http://dx.doi.org/10.1016/j. fsi.2009.01.009. PMid:19340937.

KUMARI, J. and SAHOO, P., 2005. Effects of cyclophosphamide on the immune system and disease resistance of Asian catfish Clarias batrachus. Fish \& Shellfish Immunology, vol. 19, no. 4, pp. 307-316. http://dx.doi.org/10.1016/j.fsi.2005.01.008. PMid:15863012.

LAW, W.-Y., CHEN, W.-H., SONG, Y.-L., DUFOUR, S. and CHANG, C.-F., 2001. Differential in vitro suppressive effects of steroids on leukocyte phagocytosis in two teleosts, tilapia and common carp. General and Comparative Endocrinology, vol. 121, no. 2, pp. 163-172. http://dx.doi.org/10.1006/gcen.2000.7593. PMid:11178882.

LI, J., BARREDA, D.R., ZHANG, Y.-A., BOSHRA, H., GELMAN, A.E., LAPATRA, S., TORT, L. and SUNYER, J.O., 2006. B lymphocytes from early vertebrates have potent phagocytic and microbicidal abilities. Nature Immunology, vol. 7, no. 10, pp. 1116-1124. http://dx.doi.org/10.1038/ni1389. PMid:16980980.

LIN, S., LONG, W., CHEN, J. and HOPKINS, N., 1992. Production of germ-line chimeras in zebrafish by cell transplants from genetically pigmented to albino embryos. Proceedings of the National Academy of Sciences of the United States of America, vol. 89 , no. 10, pp. 4519-4523. http://dx.doi.org/10.1073/ pnas.89.10.4519. PMid:1584786

LOBÓN-CERVIÁ, J. and BENNEMANN, S., 2000. Temporal trophic shifts and feeding diversity in two sympatric, neotropical, omnivorous fishes: Astyanax bimaculatus and Pimelodus maculatus in Rio Tibagi (Paraná, Southern Brazil). Archiv für Hydrobiologie, vol. 149 , no. 2 , pp. $285-306$. http://dx.doi.org/10.1127/archivhydrobiol/149/2000/285.

MARQUES, R.G., PETROIANU, Y. and COELHO, J.D.O., 2003. Bacterial phagocytosis by macrophage of autogenous splenic implant. Brazilian Journal of Biology $=$ Revista Brasileira de Biologia, vol. 63, no. 3, pp. 491-495. http://dx.doi.org/10.1590/ S1519-69842003000300015. PMid:14758708.

MARTINS, M.L., MYIAZAKI, D., TAVARES-DIAS, M., FENERICK JUNIOR, J., ONAKA, E.M., BOZZO, F.R., FUJIMOTO, R.Y. and MORAES, F.R.D., 2009. Characterization of the acute inflammatory response in the hybrid tambacu (Piaractus mesopotamicus male $\times$ Colossoma macropomum female)(Osteichthyes). Brazilian Journal of Biology $=$ Revista Brasileira de Biologia, vol. 69, no. 3, pp. 957-962. http://dx.doi. org/10.1590/S1519-69842009000400026. PMid:19802458.

MILLER, N., WILSON, M., BENGTÉN, E., STUGE, T., WARR, G. and CLEM, W., 1998. Functional and molecular characterization of teleost leukocytes. Immunological Reviews, vol. 166, no. 1, pp. 187-197. http://dx.doi.org/10.1111/j.1600065X.1998.tb01263.x. PMid:9914913.

MORITA, T., MORISHIMA, K., MIWA, M., KUMAKURA, N., KUDO, S., ICHIDA, K., MITSUBOSHI, T., TAKEUCHI, Y. and YOSHIZAKI, G., 2015. Functional sperm of the yellowtail (Seriola quinqueradiata) were produced in the small-bodied surrogate, jack mackerel (Trachurus japonicus). Marine Biotechnology, vol. 17, no. 5, pp. 644-654. http://dx.doi.org/10.1007/s10126015-9657-5. PMid:26239188

NAGASAWA, T., SOMAMOTO, T. and NAKAO, M., 2015. Carp thrombocyte phagocytosis requires activation factors secreted from other leukocytes. Developmental and Comparative Immunology, vol. 52, no. 2, pp. 107-111. http://dx.doi.org/10.1016/j. dci.2015.05.002. PMid:25978929.

NASCIMENTO, N.F., PEREIRA-SANTOS, M., PIVA, L.H., MANZINI, B., FUJIMOTO, T., SENHORINI, J.A., YASUI, G.S. and NAKAGHI, L.S.O., 2017a. Growth, fatty acid composition, and reproductive parameters of diploid and triploid yellowtail tetra Astyanax altiparanae. Aquaculture, vol. 471, pp. 163-171. http://dx.doi.org/10.1016/j.aquaculture.2017.01.007.

NASCIMENTO, N.F., SIQUEIRA-SILVA, D.H., PEREIRASANTOS, M., FUJIMOTO, T., SENHORINI, J.A., NAKAGHI, L.S.O. and YASUI, G.S., 2017b. Stereological analysis of gonads from diploid and triploid fish yellowtail tetra Astyanax altiparanae (Garutti \& Britski) in laboratory conditions. Zygote, vol. 25, no. 4, pp. 537-544. http://dx.doi.org/10.1017/S0967199417000399. PMid:28766472.

NEUMANN, N.F., STAFFORD, J.L., BARREDA, D., AINSWORTH, A.J. and BELOSEVIC, M., 2001. Antimicrobial mechanisms of fish phagocytes and their role in host defense. Developmental and Comparative Immunology, vol. 25, no. 8-9, pp. 807-825. http://dx.doi.org/10.1016/S0145-305X(01)00037-4. PMid:11602197.

NUNES, A.L., RODRIGUES, R.A., FANTINI, L.E., OLIVEIRA, N.S., VEIGA, P.T.N., KASAI, R.Y.D. and CAMPOS, C.M., 2014. Hematologia e tempo de migração de mácrofagos em surubim 
Pseudoplatystoma spp. frente a inoculação de Saccharomyces cerevisae. Semina: Ciências Agrárias, vol. 35, no. 2, pp. 867-874. http://dx.doi.org/10.5433/1679-0359.2014v35n2p867.

PAUL, N., CHAKRABORTY, S. and SENGUPTA, M., 2014. Lead toxicity on non-specific immune mechanisms of freshwater fish Channa punctatus. Aquatic Toxicology, vol. 152, pp. 105-112. http://dx.doi.org/10.1016/j.aquatox.2014.03.017. PMid:24747082.

PITCHER, J., LOHSE, M.J., CODINA, J., CARON, M.G. and LEFKOWITZ, R.J., 1992. Desensitization of the isolated beta 2 -adrenergic receptor by beta-adrenergic receptor kinase, cAMPdependent protein kinase, and protein kinase $C$ occurs via distinct molecular mechanisms. Biochemistry, vol. 31, no. 12, pp. 31933197. http://dx.doi.org/10.1021/bi00127a021. PMid:1348186.

RAILO, E., NIKINMAA, M. and SOIVIO, A., 1985. Effects of sampling on blood parameters in the rainbow trout, Salmo gairdneri Richardson. Journal of Fish Biology, vol. 26, no. 6, pp. 725-732. http://dx.doi.org/10.1111/j.1095-8649.1985.tb04312.x.

RANZANI-PAIVA, M.J.T., PÁDUA, S.B., TAVARES-DIAS, M. and EGAMI, M.I., 2013. Métodos para análise hematológica em peixes. 1st ed. Maringá: EDUEM, 140 p. http://dx.doi. org/10.7476/9788576286530.

ROBERTS, R.J., 2012. Fish pathology. 4th ed. Hoboken: John Wiley \& Sons, 581 p. http://dx.doi.org/10.1002/9781118222942.

ROSSI, S., SÁ-ROCHA, V., KINOSHITA, D., GENOYPUERTO, A., ZWARG, T., WERNECK, M., SÁ-ROCHA, L. and MATUSHIMA, E., 2009. Flow cytometry as a tool in the evaluation of blood leukocyte function in Chelonia mydas (Linnaeus, 1758) (Testudines, Cheloniidae). Brazilian Journal of Biology = Revista Brasileira de Biologia, vol. 69, no. 3, pp. 899-905. http://dx.doi.org/10.1590/S1519-69842009000400019. PMid:19802451.

SAITO, T., GOTO-KAZETO, R., ARAI, K. and YAMAHA, E., 2008. Xenogenesis in teleost fish through generation of germline chimeras by single primordial germ cell transplantation. Biology of Reproduction, vol. 78, no. 1, pp. 159-166. http://dx.doi. org/10.1095/biolreprod.107.060038. PMid:17901077.

SANTOS, M., YASUI, G., XAVIER, P., MACEDO, A.N., NASCIMENTO, N., FUJIMOTO, T., SENHORINI, J. and NAKAGHI, L., 2016. Morphology of gametes, post-fertilization events and the effect of temperature on the embryonic development of Astyanax altiparanae (Teleostei, Characidae). Zygote, vol. 24, no. 6, pp. 795. http://dx.doi.org/10.1017/S0967199416000101. PMid:27220819.

SECOMBES, C. and FLETCHER, T., 1992. The role of phagocytes in the protective mechanisms of fish. Annual Review of Fish Diseases, vol. 2, pp. 53-71. http://dx.doi.org/10.1016/09598030(92)90056-4

SILVA, J., STAINES, N., HERNANDEZ-BLAZQUEZ, F., PORTO-NETO, L. and BORGES, J., 2002. Phagocytosis and giant cell formation at $0{ }^{\circ} \mathrm{C}$ by macrophage (MØ) of Notothenia coriiceps. Journal of Fish Biology, vol. 60, no. 2, pp. 466-478. http://dx.doi.org/10.1111/j.1095-8649.2002.tb00294.x.

SILVA, J.R.M.C., PORTO-NETO, L.R., BORGES, J.C.S. and JENSCH-JUNIOR, B.E., 2005. Germicide capacity of macrophages (MØ) in the Antarctic fish Notothenia coriiceps (Richardson, 1844 ) at $0{ }^{\circ}$ C. Polar Biology, vol. 28, no. 4, pp. 326-328. http:// dx.doi.org/10.1007/s00300-004-0704-3.

SUZUKI, Y. and IIDA, T., 1992. Fish granulocytes in the process of inflammation. Annual Review of Fish Diseases, vol. 2, pp. 149160. http://dx.doi.org/10.1016/0959-8030(92)90061-2.
TAKEUCHI, Y., YOSHIZAKI, G. and TAKEUCHI, T., 2003. Generation of live fry from intraperitoneally transplanted primordial germ cells in rainbow trout. Biology of Reproduction, vol. 69, no. 4, pp. 1142-1149. http://dx.doi.org/10.1095/biolreprod.103.017624. PMid:12773413

TAKEUCHI, Y., YOSHIZAKI, G. and TAKEUCHI, T., 2004. Biotechnology: surrogate broodstock produces salmonids. Nature, vol. 430, no. 7000, pp. 629-630. http://dx.doi.org/10.1038/430629a. PMid:15295587.

TAVARES-DIAS, M., ONO, E., PILARSKI, F. and MORAES, F., 2007. Can thrombocytes participate in the removal of cellular debris in the blood circulation of teleost fish? A cytochemical study and ultrastructural analysis. Journal of Applied Ichthyology, vol. 23, no. 6, pp. 709-712. http://dx.doi.org/10.1111/j.14390426.2007.00850.x.

TIZARD, I., 2014. Imunologia veterinária. 9th ed. Rio de Janeiro: Saunders, $568 \mathrm{p}$.

WALSH, C.J., WYFFELS, J., BODINE, A. and LUER, C., 2002. Dexamethasone-induced apoptosis in immune cells from peripheral circulation and lymphomyeloid tissues of juvenile clearnose skates, Raja eglanteria. Developmental and Comparative Immunology, vol. 26, no. 7, pp. 623-633. http://dx.doi.org/10.1016/ S0145-305X(02)00016-2. PMid:12074927.

XING, J., XIAO, Y.E., TANG, X., SHENG, X. and ZHAN, W., 2017. Inhibition of Cyclosporine A or rapamycin on $T$ lymphocyte counts and the influence on the immune responses of B lymphocytes in flounder (Paralichthys olivaceus). Fish \& Shellfish Immunology, vol. 66, pp. 78-85. http://dx.doi.org/10.1016/j. fsi.2017.05.017. PMid:28483552.

YAMAHA, E., SAITO, T., GOTO-KAZETO, R. and ARAI, K., 2007. Developmental biotechnology for aquaculture, with special reference to surrogate production in teleost fishes. Journal of Sea Research, vol. 58, no. 1, pp. 8-22. http://dx.doi.org/10.1016/j. seares.2007.02.003.

YASUI, G.S., FUJIMOTO, T., SAKAO, S., YAMAHA, E. and ARAI, K., 2011. Production of loach (Misgurnus anguillicaudatus) germ-line chimera using transplantation of primordial germ cells isolated from cryopreserved blastomeres 1. Journal of Animal Science, vol. 89, no. 8, pp. 2380-2388. http://dx.doi.org/10.2527/ jas.2010-3633. PMid:21398566.

YASUI, G.S., SENHORINI, J.A., SHIMODA, E., PEREIRASANTOS, M., NAKAGHI, L.S.O., FUJIMOTO, T., ARIASRODRIGUEZ, L. and SILVA, L.A., 2015. Improvement of gamete quality and its short-term storage: an approach for biotechnology in laboratory fish. Animal, vol. 9, no. 3, pp. 464-470. http://dx.doi. org/10.1017/S1751731114002511. PMid:25391393.

YOSHIKAWA, H., TAKEUCHI, Y., INO, Y., WANG, J., IWATA, G., KABEYA, N., YAZAWA, R. and YOSHIZAKI, G., 2017. Efficient production of donor-derived gametes from triploid recipients following intra-peritoneal germ cell transplantation into a marine teleost, Nibe croaker (Nibea mitsukurii). Aquaculture, vol. 478, pp. 35-47. http://dx.doi.org/10.1016/j.aquaculture.2016.05.011.

ZHU, H., LIU, H., YAN, J., WANG, R. and LIU, L., 2012. Effect of yeast polysaccharide on some hematologic parameter and gut morphology in channel catfish (Ictalurus punctatus). Fish Physiology and Biochemistry, vol. 38, no. 5, pp. 1441-1447. http://dx.doi.org/10.1007/s10695-012-9631-3. PMid:22437370. 